\title{
Purification of Labeled Antibodies Using Size-Exclusion Chromatography
}

\author{
Eric A. Berg and Jordan B. Fishman
}

Many antibody labeling procedures call for a desalting or purification step requiring size-exclusion chromatography (SEC). The method outlined here contains information needed to desalt an antibody conjugate. Similar procedures would be used for ion-exchange chromatography using a gradient of increasing ionic strength. Resins can be purchased in bulk (as in this protocol), or commercially available columns are available.

MATERIALS

It is essential that you consult the appropriate Material Safety Data Sheets and your institution's Environmental Health and Safety Office for proper handling of equipment and hazardous materials used in this protocol.

Reagents

\section{$\mathrm{DiH}_{2} \mathrm{O}$}

Labeled antibody solution

Running buffer: PBS, Tris, HEPES, MES (type and $\mathrm{pH}$ will depend on the application)

Size-exclusion gel matrix (e.g., Sephadex; choice dependent on size of conjugate; see Table 1)

Table 1 provides a list of SEC Sephadex resins and the effective separation range of each. Typically manufacturers give a volume/milliliter value. Your volume of sample should be no more than $5 \%$ of the column volume for desalting and no more than $2 \%$ of the column volume when separating molecules that are close in size.

Equipment

Chromatography equipment (optional)

Prepoured columns are available, but even common laboratory materials (i.e., 10-mL syringe with filter paper or frit) can be adapted for use.

Glass or polypropylene column

Glass or polypropylene tubes

Glassware (beaker or flask)

Peristaltic pump (optional)

Spectrophotometer

From the Antibodies collection, edited by Edward A. Greenfield.

(C) 2020 Cold Spring Harbor Laboratory Press

Cite this protocol as Cold Spring Harb Protoc; doi:10.1101/pdb.prot099358 
E.A. Berg and J.B. Fishman

TABLE 1. SEC Sephadex resins and the effective separation range of each

\begin{tabular}{lll}
\hline Sephadex & MW range & Application \\
\hline G-10 & $\leq 700$ & Very-low MW substances; desalting; buffer exchange: peptides \\
G-15 & $\leq 1500$ & Very-low MW substances; desalting; buffer exchange: peptides \\
G-25 & $1000-5000$ & Most common for desalting; buffer exchange: small peptides and proteins \\
G-50 & $1500-30,000$ & Desalting; buffer exchange: small peptides and proteins \\
G-75 & $30,000-80,000$ & Protein separation \\
G-100 & $4000-150,000$ & Protein conjugate separation \\
G-150 & $5000-300,000$ & Protein conjugate separation; protein complexes-low noncovalent interactions \\
G-200 & $5000-600,000$ & Protein conjugate separation; protein complexes-low noncovalent interactions \\
\hline
\end{tabular}

\section{METHOD}

1. Swell the resin in $200-300 \mathrm{~mL}$ of $\mathrm{DiH}_{2} \mathrm{O}$ overnight at room temperature.

Some resins require different swelling conditions including degassing. Refer to the manufacturer's instructions.

2. Decant the liquid without losing the swelled gel.

3. Wash the gel twice with $\mathrm{DiH}_{2} \mathrm{O}$, letting the matrix settle and decanting the liquid.

4. Replace the $\mathrm{DiH}_{2} \mathrm{O}$ with running buffer. Let the gel settle, decant, and add fresh running buffer. Repeat this again.

5. Pour the swelled gel into a column and allow it to settle using either gravity or a pump.

6. When adding additional matrix, gently stir the interface with a sterile pipette.

Keeping the poured resin as continuous as possible will ensure the best separation.

7. Equilibrate the column with either 10 column volumes of buffer, or if the buffer was replaced during the swelling process (Step 4), then two column volumes will be sufficient.

8. Expose the gel bed and gently load the sample onto the gel bed, minimizing disturbance of the surface.

9. Allow the sample to completely enter the gel bed, and then begin to gently add running buffer to the gel bed.

10. Collect $0.5-\mathrm{mL}$ fractions from the column.

11. After several milliliters of running buffer have entered the gel bed, additional buffer can be added to the top of the gel.

12. Measure the OD of the fractions in a spectrophotometer. The first peak is the antibody and should begin to elute in approximately the sixth fraction. Pool the main peak and measure the OD again to determine the antibody concentration.

See Troubleshooting.

13. Store the antibody conjugate as described above and in Introduction: Antibody Purification and Storage (Berg and Fishman 2019).

Problem (Step 12): The protein elutes too quickly (crack in column).

Solution: Collect the sample, concentrate, repour the column, and repeat the protocol.

Problem (Step 12): The protein elutes too slowly (wrong sizing matrix chosen).

Solution: Use a different matrix that separates in a smaller MW range. 


\section{RELATED INFORMATION}

A general review of chromatography theory and techniques can be found in Snyder et al. (2010).

\section{REFERENCES}

Berg EA, Fishman JB. 2019. Antibody purification and storage. Cold Spring Harb Protoc doi: 10.1101/pdb.top099101.
Snyder LR, Kirkland JJ, Dolan JW. 2010. Introduction to modern liquid chromatography, 3rd ed. Wiley, New York. 


\section{Purification of Labeled Antibodies Using Size-Exclusion Chromatography}

Eric A. Berg and Jordan B. Fishman

Cold Spring Harb Protoc; doi: 10.1101/pdb.prot099358

\begin{tabular}{|c|c|}
\hline $\begin{array}{r}\text { Email Alerting } \\
\text { Service }\end{array}$ & Receive free email alerts when new articles cite this article - click here. \\
\hline $\begin{array}{r}\text { Subject } \\
\text { Categories }\end{array}$ & $\begin{array}{l}\text { Browse articles on similar topics from Cold Spring Harbor Protocols. } \\
\text { Antibodies (119 articles) } \\
\text { Antibodies, general (289 articles) } \\
\text { Chromatography (47 articles) } \\
\text { Handling Antibodies (43 articles) } \\
\text { Purifying Antibodies (18 articles) } \\
\text { Size-Exclusion Chromatography (11 articles) }\end{array}$ \\
\hline
\end{tabular}

